\title{
SPARC Gene
}

National Cancer Institute

\section{Source}

National Cancer Institute. SPARC Gene. NCI Thesaurus. Code C92666.

This gene is involved in the regulation of cellular morphology, extracellular matrix deposition and cell cycle progression. 